\section{Colour Inheritance in Silkworms}

MPORTANT results and conclusions regarding the 1 inheritance of cocoon colour in silkworms have recently been published*. In these insects the colour of the silk secreted generally corresponds with that of the hæmolymph. Breeds with white cocoons have colourless blood, while those with yellow cocoons have yellow blood. In different strains the yellow varies from golden to straw-colour or reddish yellow, and some silkworms with yellow blood may weave a white cocoon, but it is not possible for a silkworm having white blood to produce a yellow cocoon.

It is concluded that migration of pigment takes place from the blood to the silk secretion. In some strains there is a change of colour in the different layers of the cocoon. For example, in the Chinese the outer layer is yellow-gold, becoming gradually paler to pure white in the innermost layer. The cocoon of the Italian strain, however, is colourless outside, becoming deeper coloured towards the interior. The colour is derived from the carotinoid pigments of the mulberry leaf, but its tint and distribution appear to depend on the conditions in which the pigment passes from the blood to the silk.

Two races with white $(W)$ cocoons may, when crossed, produce a strain having yellow $(Y)$ cocoons if one is white because the blood is unpigmented and the other because of incapacity of the silk gland to extract pigment from the blood. The possibility of migration of blood pigment to the silk is inherited as a dominant Mendelian character, but races differ in the time at which the silk glands show this capacity for taking up pigment. Thus in the Italian strain 'Fossombrone' the cocoon is nearly white in its outer layers, becoming golden yellow within, while in the Chinese yellow the outer layers of the cocoon are yellow. In crosses between them, this difference in 'precocity' of the action of the silk gland gives an intermediate result in the hybrid. Such results account for various discrepancies and the 'maternal inheritance' obtained by earlier investigators.

The colourless blood and white cocoons of the Japanese 'Awojiku' and other recessive whites is believed to be due to absence of capacity for absorbing the carotinoid pigments from the food through the intestinal wall; while in such dominant white strains as 'Baghdad' the colourless blood may be due to the presence of oxidising enzymes. In a green strain the pigment is a flavone derived from the leaf, which is present also in certain other strains. Thus not only are intestinal permeability and glandular permeability independent, but permeability to the flavones and the carotinoids are separate characters. White 'Awojiku' $\times$ 'Green' gives an $F_{1}$ with white blood and a $15:$ I ratio in $F_{2}$. The explanation of this dihybrid result is not yet clear.

It is found that the pigments can be quantitatively extracted from the cocoons of various types. By these methods it is possible not only to reach a physio. logical definition of the hereditary factors in terms of cell permeability, but also to investigate the chemico-physiological individuality of the substances the metabolism of which is controlled by these genetic factors.

R. R. G. Studi di Genetica sui Bachi da Seta. Per Carlo Jucci. I: In
Colore del Bozzolo. Reale Accad. d'Italia, Mem. Classe Fis., Matemat. e Naturali. Vol. 5, pp. 347-477; 1934.

\section{Educational Topics and Events}

Cambridge.-The Frank Smart studentship in botany will be vacant on October 1, 1935. Any graduate of the University is eligible for the studentship provided that not more than fourteen complete terms have elapsed after his first term of residence. The value of the studentship is $£ 200$ per annum. A candidate must send his name, with a statement of the course of research he proposes to undertake, to Prof. A. C. Seward at the Botany School on or before October 2 .

From the Kaiser-Wilhelm-Gesellschaft zur Förderung der Wissenschaften we have received two polyglot pamphlets describing the scope of the Society's work, which embraces the maintenance of thirty-four research institutes in Berlin, Heidelberg, Dortmund, Munich, Göttingen, Düsseldorf, Breslau, Dresden, the Ruhr and other places in Germany, Austria, Italy, Switzerland and Brazil. An appeal is made for the moral and material support of Germans the world over (in the English version, erroneously, "the widest circles in Germany"). One of the pamphiets relates to "Harnack House" in Berlin, a hostel for foreign visitors engaged in research in subjects germane to those studied in the Society's institutes. Here they have opportunities of intercourse with German savants, for the hostel serves also as a club for members of the Society and the staffs of the Institutes, about 150 of whom take their meals there every day. The House has a library, reading-room with numerous German and foreign periodicals, gymnasium, tenniscourts, bathrooms, lounge, terraces, etc. It is used by various learned societies for lectures and social functions, and is described as having become the centre of intellectual life in Berlin.

UNIVERSITY student housing conditions, past and present, form the subject of two interesting articles by Dr. W. H. Cowley, of Ohio State University, in School and Society of December 1 and 8. Nearly all the founders of the American colonial colleges were Oxford and Cambridge graduates or English-educated Americans ; but the English college system of bring. ing together dons and students both for formal individual conferences and for informal social and intellectual intercourse failed to reproduce itself in the United States. College residential conditions were affected not only by the undeveloped state of the country, but also particularly by the bogey of student discipline, responsibility for which rested on the faculty member living in the dormitory, and this led to acute faculty-student antipathies. In the course of the nineteenth century, German university ideals became dominant in America and, as these recognised no obligation on the part of the university to concern itself with the life of the student outside the classroom, dormitories came to suffer from neglect where not dispensed with. Towards the end of the century a reaction began, and though considerably hampered by the recent general economic depression, is still active and promises to become even more important. The Oxford and Cambridge college system has now been adopted more or less at Harvard and Yale, the German point of view still prevails at California and Nebraska, and an American compromise, giving students body shelter and varying degrees of social education, is general. 